\title{
Long-term recruitment of soft-corals (Octocorallia: Alcyonacea) on artificial substrata at Eilat (Red Sea)
}

\author{
Y. Benayahu \& Y. Loya \\ Department of Zoology, The George S. Wise Center for Life Sciences, Tel Aviv University, Tel Aviv 69978, Israel
}

\begin{abstract}
Recruitment of soft corals (Octocorallia: Alcyonacea) on concrete plates was studied in the reefs of the Nature Reserve of Eilat at depths of 17 to $29 \mathrm{~m}$ over $12 \mathrm{yr}$. Xenia macrospiculata was the pioneering species, appearing on the vast majority of the plates before any other spat. This species remained the most conspicuous inhabitant of the substrata throughout the whole study. Approximately $10 \%$ of the plates were very extensively colonized by $X$. macrospiculata, resembling the percentage of living coverage by the species in the surrounding reef, thus suggesting that during the study $X$. macrospiculata populations reached their maximal potential to capture the newly available substrata. The successive appearance of an additional 11 soft coral species was recorded. The species composition of the recruits and their abundance corresponded with the soft coral community in the natural reef, indicating that the established spat were progeny of the local populations. Soft coral recruits utilized the edges and lower surfaces of the plates most successfully, rather than the exposed upper surfaces. Such preferential settling of alcyonaceans allows the spat to escape from unfavourable conditions and maintains their high survival in the established community.
\end{abstract}

\section{INTRODUCTION}

Studies on processes and dynamics of reef benthic organisms are concerned mainly with hermatypic corals. A variety of biological and ecological aspects have been examined on their recruitment (Loya 1976, Birkeland et al. 1981, Colgan 1981, Neudecker 1981, Pearson 1981, Wallace \& Bull 1981, Coles 1984, Rogers et al. 1984, Sakai \& Yamazato 1984, Baggett \& Bright 1985, Fitzhardinge 1985, Harriott 1985, Hughes 1985, Sammarco 1985, Wallace 1985). Strikingly, studies dealing with such features among soft corals (Octocorallia: Alcyonacea) are sparse. Most of the current information on their recruitment capabilities is derived from more general reef surveys (Schuhmacher 1974, Bouchon et al. 1981; see Pearson 1981 for further references).

It has been shown that some soft corals are capable of translocation and are therefore able to quickly take over reef substrata (Benayahu \& Loya 1981, 1985, La Barre \& Coll 1982, Dinesen 1985). However, quantitative data concerning formation of soft coral communities on newly available substrata is practically lacking. Such information is of primary importance to determine the role played by alcyonaceans in the course of reef colonization and in the reef's space allocation.

In the present study, we followed recruitment of soft corals on artificial substrata in Eilat reefs over a 12 yr period. This is the first long-term quantitative account which deals exclusively with settling patterns of reef alcyonaceans and formation of their assemblages.

\section{MATERIALS AND METHODS}

To study recruitment of soft corals we set out 90 concrete plates, each with a surface of $50 \times 50 \mathrm{~cm}$ (2500 $\mathrm{cm}^{2}$ on each side) and $4 \mathrm{~cm}$ thick. The plates were laid down on the reef of Eilat Nature Reserve, Israel, in August 1973, at depths from 17 to $29 \mathrm{~m}$. This area has a well-developed reef with high diversity of stony corals (Loya 1972) and rich assemblages of soft corals (Benayahu 1982). The plates were set out from the R/V Arnona of the Marine Biological Laboratory of Eilat, at a site marked by floats. To avoid sand coverage, SCUBA divers positioned the plates obliquely onto hard natural substrata. Each plate was marked by 
a numbered tag, attached to a neighbouring reef projection.

During the first $2.5 \mathrm{yr}$ after exposure of the plates to settlement (August 1973 to February 1976), recruitment was recorded every $3 \mathrm{mo}$. Thereafter, for the following 5 yr (until Feb 1981), the plates were examined every 2 to $5 \mathrm{mo}$. The abundance and identity of all species on each plate were recorded using SCUBA equipment. In addition, the orientation of the recruits on the plates was routinely documented, indicating whether attachment took place on the exposed upper surface, or on the edges of each plate. All recruits except for Xenia macrospiculata spat were individually marked by piercing wired tags through the colonies. Settlement on the lower side of the plates was documented in February 1980 . For this purpose each plate was carefully removed from its position, searched by SCUBA divers for hidden spat, then replaced in its original site and position. An additional survey of the plates was carried out in August 1985, 12 yr after the initiation of the experiment. Since most of the tags were lost over the years, this final examination only yielded information regarding the total species composition and abundance on the 90 plates.

\section{RESULTS}

During the first months following the initiation of the study, a low and sparse algal coverage was established on the plates. Among the alcyonaceans, colonies of Xenia macrospiculata Gohar were the pioneering recruits. X. macrospiculata colonies were already recorded on some plates within the first weeks after initiation of the study. On the vast majority of the plates $X$. macrospiculata appeared before any scleractinian spat (Loya unpubl. data). This species remained the most conspicuous inhabitant on the plates throughout the study. The initial rapid recruitment of $X$. macro-

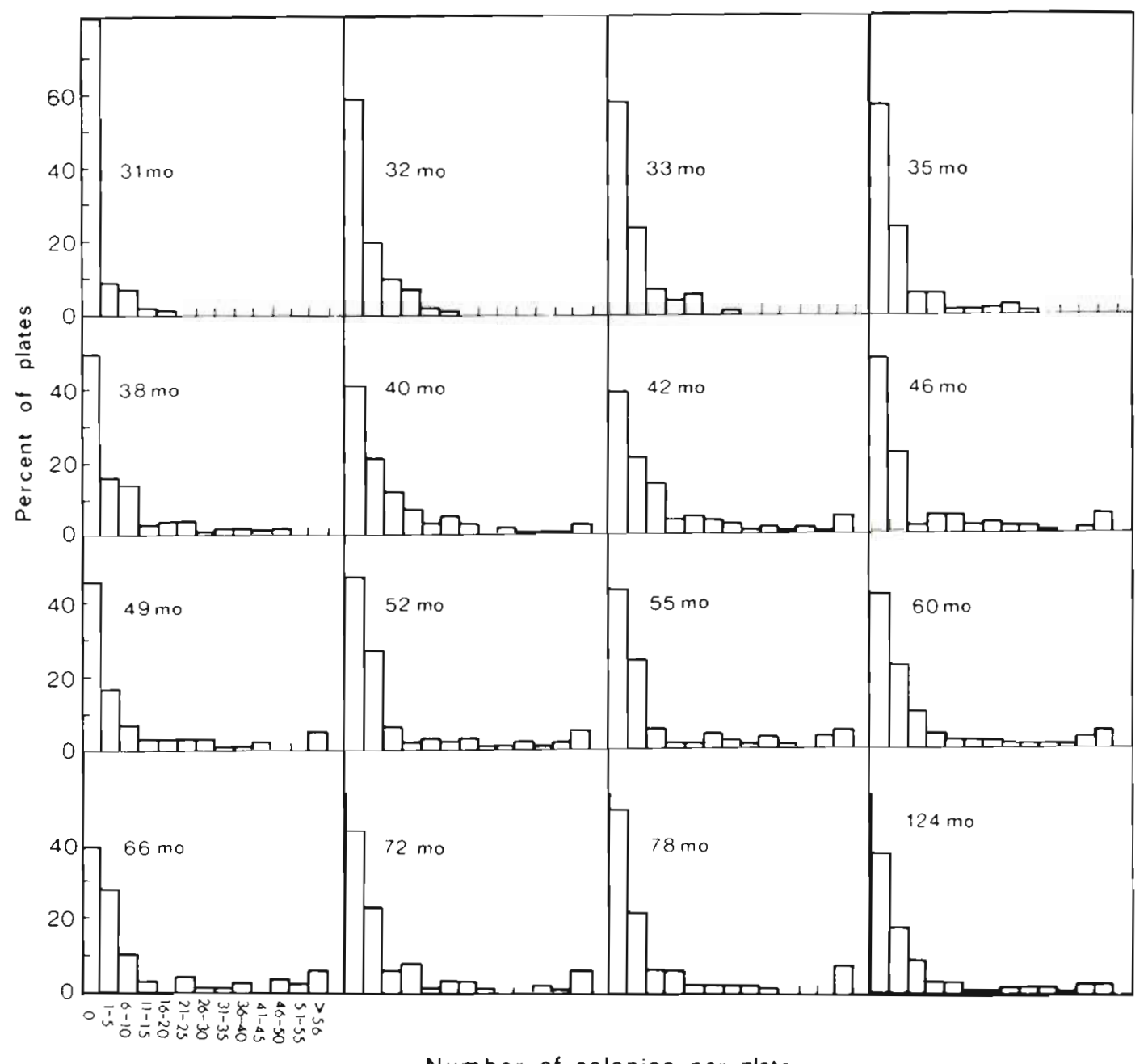

Number of colonies per plate

Fig. 1. Xenia macrospiculata settlement on 90 concrete plates at Eilat reef. Time from initiation of the experiment is indicated beside each histogram 
spiculata colonies was a result of translocation from adjacent natural substrates onto the experimental plates (Benayahu \& Loya 1985). As time progressed, further translocation took place and asexual colony fission of these recruits gradually increased their density (Benayahu \& Loya 1985). Sexual spat of $X$. macrospiculata, which developed from planulae, were also recorded on the experimental surfaces (see below).
Fig. 1 presents the relative percentage of plates settled by various densities of Xenia macrospiculata throughout the study. Observations after 31 mo indicated rather low X. macrospiculata densities. However, Fig. 1 demonstrates the successive increase of $X$. macrospiculata abundance with time coupled with the decreasing number of non-colonized plates. Note that 31 mo after the initiation of the experiment $80 \%$ of the

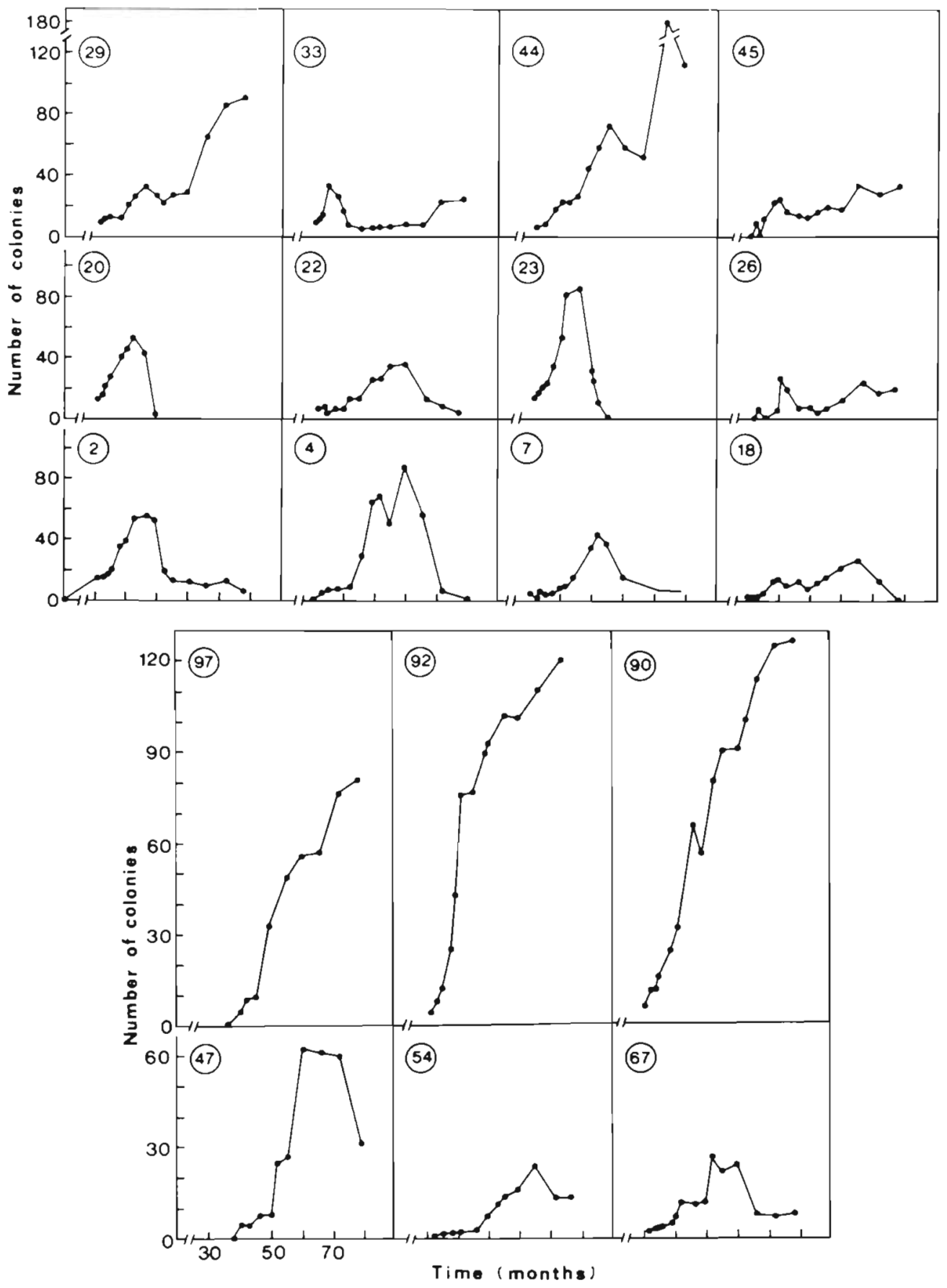

Fig. 2. Xenia macrospiculata population dynamics on 18 highly populated plates. Circled numbers represent the tag number of the plate 
substrates lack any $X$. macrospiculata spat. The last census, carried out 12 yr after the experimental set up, demonstrated that $40 \%$ of the plates were free of $X$. macrospiculata. Remarkable densities of $X$. macrospiculata were recorded on several substrates (Fig. 1: $>56$ colonies per plate). These particular plates were monopolized by X. macrospiculata, with a 80 to $100 \%$ coverage of their exposed surface area.

Dynamics of recruitment on the 18 most densely populated plates is presented in Fig. 2. High Xenia macrospiculata coverage on the upper surface (Fig. 3a) and edges of the plates (Fig. 4a) occurred on plates with more than 100 colonies. On some substrata (e.g. Nos 90, 92, 97) a rapid increase in density was recorded. Density fluctuations of $X$. macrospiculata with time were observed on some other plates (e.g. Nos $26,33,45)$. Another pattern observed was a gradual increase in density, followed by a steep decline (e.g. Nos $18,20,23)$. These patterns are affected by settlement and mortality of the spat and thus represent net recruitment (see 'Discussion').

Recruitment of Xenia macrospiculata far exceeded that of any other species (Fig. 3a). Nevertheless, several additional soft coral species settled on the plates. A total number of 69 octocoral colonies (excluding $X$.
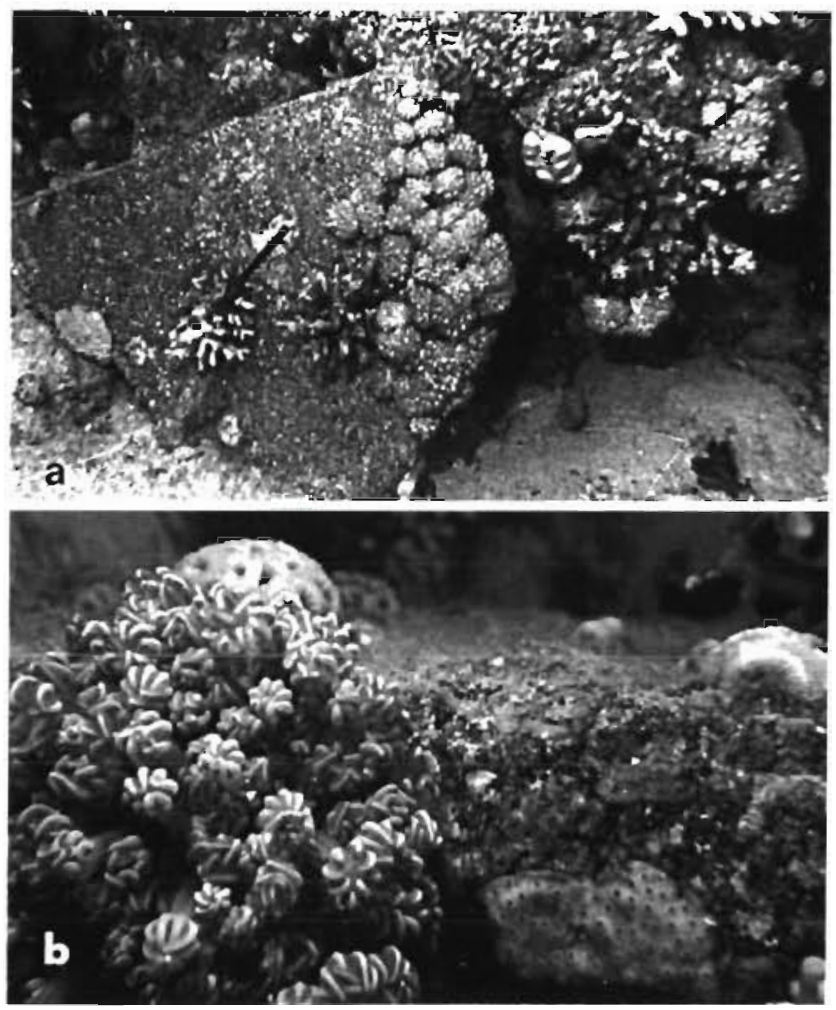

Fig. 3. (a) Xenia macrospiculata settlement on an experimental plate. Arrow indicates a living colony of the scleractinian coral Stylophora pistillata. (b) Heteroxenia fuscescens: mature colony growing on an edge of a plate $(\times 0.5)$
Table 1. Abundance of octocorals other than Xenia macrospiculata on the settling plates $12 \mathrm{yr}$ after initition of the experiment $(n=69)$

\begin{tabular}{|c|c|c|}
\hline \multicolumn{2}{|c|}{$\begin{array}{l}\text { Species } \\
\text { rank }\end{array}$} & \multirow{2}{*}{$\begin{array}{c}\% \\
\begin{array}{c}\text { Abun- } \\
\text { dance }\end{array} \\
33\end{array}$} \\
\hline 1 & Parerythropodium fulvum fulvum (Forskål) & \\
\hline 2 & Paralemnalia thyrsoides (Ehrenberg) & 13 \\
\hline 3 & Sarcophyton glaucum (Quoy \& Gaimard) & 12 \\
\hline 4 & Litophyton arboreum (Forskål) & 12 \\
\hline 5 & Heteroxenia fuscescens (Ehrenburg) & 9 \\
\hline 6 & Dendronephthya hartmeyeri (Kükenthal) & 7 \\
\hline 7 & Stereonephthya cundabiluensis Verseveldt & 6 \\
\hline 8 & Tubipora musica Linneus & 3 \\
\hline 9 & Anthelia glauca Lamarck & 3 \\
\hline 10 & Nephthea chabrolii Audouin & 1 \\
\hline 11 & Sinularia sp. & 1 \\
\hline
\end{tabular}

macrospiculata spat) were recorded 12 yr after the initiation of the survey (Table 1 ). The first 5 ranked species (Table 1) comprised $79 \%$ of the spat. The abundance of the remaining species was rather low. The first recruits of Parerythropodium fulvum fulvum appeared during the third year of the study. They exhibited a rapid growth rate, forming colonies with approximately $30 \mathrm{~cm}^{2}$ surface area within 1 yr. Recruits of Paralemnalia thyrsoides settled in a contagious pattern and propagated asexually by colony fission. Small aggregates of Sarcophyton glaucum and Litophyton arboreum were also established. Heteroxenia fuscescens colonies were individually located on some plates (Fig. 3b).

Most of the recruitment took place along the edges of the plates (Table 2; Fig. $3 b \& 4 a$ ). This settlement pattern is noteworthy, since the surface area of the edges is more than 3 times smaller than the available upper-plate surface (see 'Materials and Methods'). Most of the xeniid juveniles (sexual recruits) were recorded on the lower surfaces of the plates (Fig. 4b) and rarely on their edges (Fig. 4c). Hardly any juveniles were found on the upper surfaces. Colonies attached to the lower surface of the plates gradually moved, as they grew in size, to the exposed surfaces of the plates.

Table 2. Distribution of recruits on various surfaces of the expermental plates

\begin{tabular}{|c|c|c|c|}
\hline \multirow[t]{2}{*}{ Species } & \multicolumn{3}{|c|}{ Percentage of recruits } \\
\hline & Edges & $\begin{array}{l}\text { Upper } \\
\text { sides }\end{array}$ & $\begin{array}{l}\text { Lower } \\
\text { sides }\end{array}$ \\
\hline Xenia macrospiculata & 59 & 28 & 13 \\
\hline $\begin{array}{l}\text { Parerythropodium fulvum } \\
\text { fulvum }\end{array}$ & 84 & 4 & 12 \\
\hline Other soft corals & 58 & 16 & 26 \\
\hline
\end{tabular}



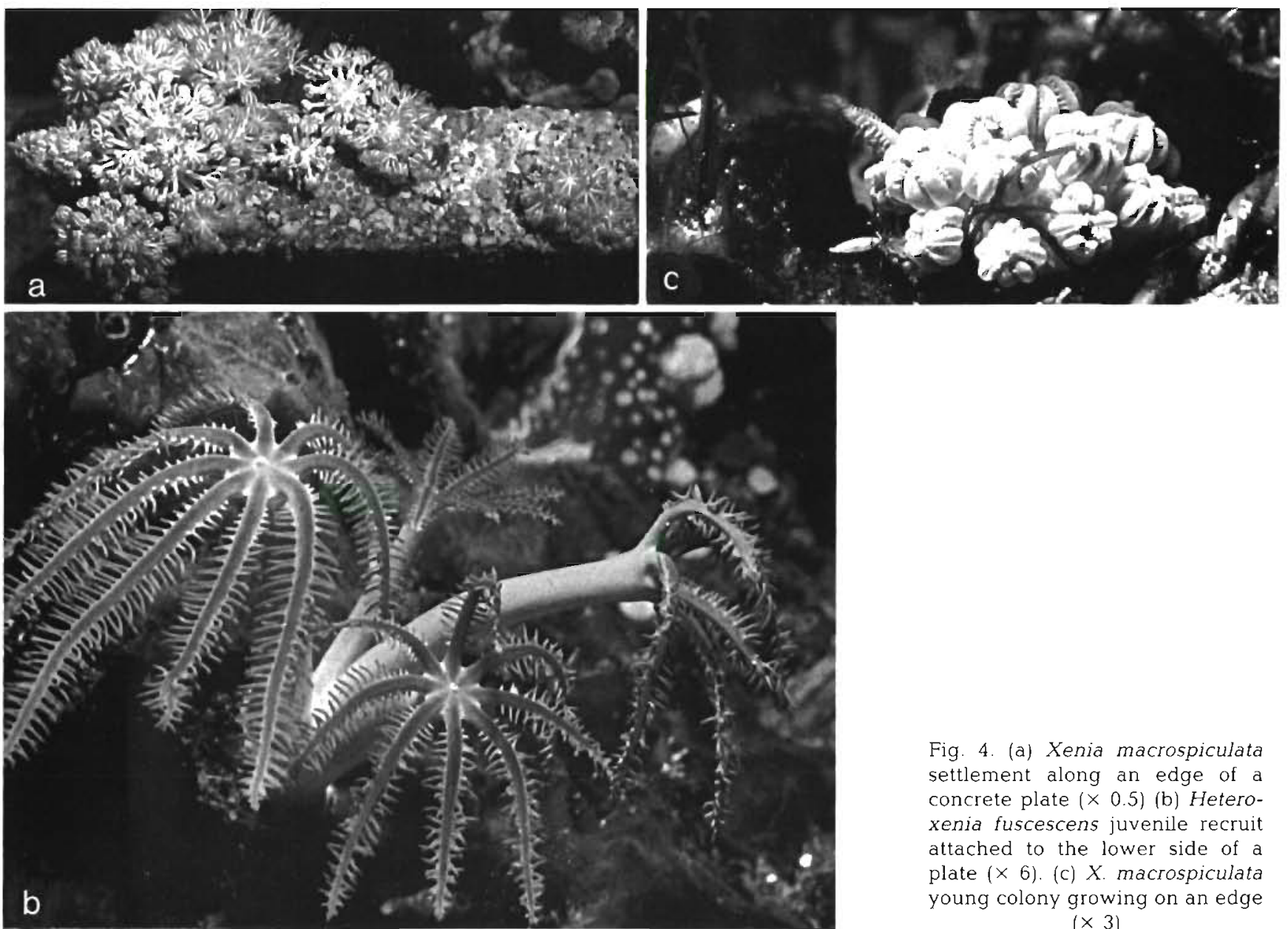

Fig. 4. (a) Xenia macrospiculata settlement along an edge of a concrete plate $(\times 0.5)$ (b) Heteroxenia fuscescens juvenile recruit attached to the lower side of a plate $(\times 6)$. (c) $X$. macrospiculata young colony growing on an edge $(\times 3)$

Juveniles of Parerythropodium fulvum fulvum, composed of a few polyps each, were most commonly attached to the edges. Through further growth, these colonies tended to cover the upper plate area. Upsidedown attachment on lower surfaces of the plates was recorded along the whole depth gradient (17 to $29 \mathrm{~m}$ ).

\section{DISCUSSION}

The present study indicated that colonization of the newly exposed plates led to formation of alcyonacean assemblages predominated by Xenia macrospiculata. $X$. macrospiculata colonies were recorded prior to any scleractinian corals, indicating their pioneering colonization capability. Recruitment and space occupation are strongly affected by presence of propagules. Planulae of $X$. macrospiculata are available annually during the breeding season, which is restricted to a certain period of the year (Benayahu 1982, Benayahu \& Loya 1984). However, in addition to sexual recruitment, $X$. macrospiculata exhibits rapid space acquisition all year round, by translocation of colonies and asexual propagation (Benayahu \& Loya 1985).

The study area at the reef of the Eilat Nature Reserve has a diverse scleractinian community with a high live cover (Loya 1972) leading to extensive competition for space in this area (Abelson unpubl. data). Therefore, the persistent increase in abundance of Xenia macrospiculata on the plates (Fig. 1) emphasizes the vigorous competitive capabilities of this species (Benayahu \& Loya 1985). The densities of $X$. macrospiculata observed in the study reveal net recruitment. Factors positively affecting this recruitment include high fecundity, prolonged period of planulation and early onset of reproduction (Benayahu \& Loya 1985). These characteristics, together with the afore-mentioned colony fission and translocation, account for the flourishing of $X$. macrospiculata on the plates. Decline of the recruits' density has been caused by occasional translocation of $X$. macrospiculata colonies from the experimental plates to neighbouring natural substrates (Benayahu \& Loya 1985). Some mortality due to smothering by sediment, mainly affecting juvenile 
recnuits, may also occur (Grigg 1977). Neither competitive exclusion by other recruits nor predation destroyed the established spat of $X$. macrospiculata. Variation in recruitment of $X$. macrospiculata on the experimental plates (Fig. 2) may be affected by spatial differences in larval abundance and dispersal. Variable distribution of the recruits may reflect a differential survivorship among the plates, most probably caused by grazing or sedimentation as suggested by Fitzhardinge (1985) for scleractinian corals. Wallace (1985) found that differences in recruitment of stony corals is a result of smallscale location effects. The recruitment patterns obtained in this study (Fig. $1 \& 2$ ) supply additional evidence for this effect in processes involved in reef colonization.

Approximately $10 \%$ of the plates were extensively colonized by Xenia macrospiculata (Fig. 1 \& 2), a value which closely resembles the percentage living coverage of $X$. macrospiculata on the surrounding reef (Benayahu 1982). We therefore suggest that during the 12 yr of study, $X$. macrospiculata reached its maximal potential in utilizing the plates. We propose that during this long period an equilibrium was established between the $X$. macrospiculata spat on the experimental plates and on natural reef substrata.

The natural soft coral community in the study area is composed mainly of Xenia macrospiculata along with some other species such as Parerythropodium fulvum fulvum, Paralemnalia thyrsoides, Sarcophyton glaucum and Litophyton arboreum (Benayahu 1982). Alcyonacean species composition and abundance on the plates (Table 1) resemble the community features of the neighbouring natural reef. This similarity strongly suggests that most of the recruits were progeny of the local populations. The planktonic phase of planulae of $X$. macrospiculata and P. f. fulvum is less than $2 \mathrm{~d}$ (Benayahu \& Loya 1984). Additional evidence indicates that such a short pelagic phase is widespread also among other alcyonaceans (Benayahu 1982, Benayahu unpubl.). Such a dispersal pattern of planulae enhances patchy distribution of species and localizes the potential for recruitment to particular reef areas. In a space-limited environment this may be beneficial, even for corals with low fecundity, since the larvae are already in an appropiate habitat type (Sebens 1983). In addition, the close resemblance between recruitment (Table 1) and soft coral abundance on the natural reef suggest that post-recruitment events (Harriott 1985) play only a minor role in determining alyconacean abundance. This does not exclude the possibility of the future appearance of some rare species on the plates. However, these additional species will not cause any dramatic changes in the characteristics of the established soft coral assemblages (see also Hughes 1985).

The massive recruitment on the edges of the plates
(Table 2; Fig. 3b \& 4a) indicates a remarkable settling preference. This settling preference was related by Foster (1975) to water flow patterns. Turbulent eddies result from flow separation associated with water movement over edges. Low water speed in these eddies may enhance larval settlement and higher survival of adults (Foster 1975).

Settlement of soft corals on the lower-side of the plates (Table 2; Fig. 4b) fits well with previous laboratory studies, indicating that planulae of Xenia macrospiculata and Parerythropodium fulvum fulvum are endowed with upside-down settling behaviour (Benayahu \& Loya 1984). Higher rate of recruitment of planula larvae on undersurfaces or on vertical substrates, rather than on exposed horizontal areas, has been pointed out in many studies (Birkeland 1977, Bak \& Engel 1979, Birkeland et al. 1981, Neudecker 1981, Wallace \& Bull 1981, Sebens 1983). Such patterns are interpreted as a response to light intensity, algal turf development, grazing pressure and sediment accumulation (Rogers et al. 1984). A consensus emerges from the literature that with increased depth (lower light intensities), orientation of recruits shifts from vertical to mostly upper horizontal positions. Planulae of $X$. macrospiculata and $P$. f. fulvum exhibit a remarkable upsidedown settlement even in shallow reefs (Benayahu \& Loya 1984). In view of these results and the findings of the current study (Table 2), we propose that soft coral juveniles most successfully utilize overhanging substrates or their edges rather than exposed upper horizontal areas.

Previous studies dealing with recovery of reefs and their recolonization by alcyonaceans demonstrated some of the soft coral capabilities of colonizing various substrata (Pearson 1981). Colonization of space is eventually determined by life-history strategies of the species, coupled with various abiotic determinants. Further long-term surveys dealing with such issues will elucidate the role undertaken by reef soft corals and the particular factors governing their successful recruitment.

Acknowledgements. We extend our gratitude to L. Fishelson. $\mathrm{H}$. Lasker and $\mathrm{K}$. Muzik for many constructive comments on the manuscript. We are grateful to $Y$ Shlesinger, $Z$. Wolodarsky, B. Rinkevich, A. Shafir and A. Abelson for diving assistance.

\section{LITERATURE CITED}

Baggett, L. S., Bright, T J. (1985). Coral recruitment at the East Flower Garden Reef (Northern Gulf of Mexico). Proc. 5th Coral Reef Congr., Tahiti 4: 379-384

Bak, R. P. M., Engel, M. S. (1979). Distribution, abundance and survival of juvenile hermatypic corals (Scleractinia) and the importance of life history strategies in the parent coral community. Mar. Biol. 54: 341-352

Benayahu, Y. (1982). Population dynamics of soft corals 
(Octocorallia, Alcyonacea) at the coral reefs of the Gulf of Eilat. Ph. D. thesis, Tel Aviv University. (Hebrew; English summary)

Benayahu, Y., Loya, Y (1981). Competition for space among coral-reef sessile organisms at Eilat, Red Sea. Bull. mar. Sc1. 31:514-522

Benayahu, Y., Loya, Y (1984). Substratum preferences and planulae settling of two Red Sea soft corals: Xenia macrospiculata Gohar and Parerythropodium fulvum fulvum (Forskål). J. exp. mar Biol. Ecol. 83: 249-261

Benayahu, Y., Loya, Y. (1985). Settlement and recruitment of a soft coral: why is Xenia macrospiculata a successful colonizer? Bull. mar Sci. 36: 177-188

Birkeland, C. (1977). The importance of rate of biomass accumulation in early successional stages of benthic communities to the survival of coral recruits. Proc. 3rd Int Coral Reef Symp., Miami 1: 15-21

Birkeland, C., Rowley, D., Randall, R. H. (1981). Coral recruitment patterns at Guam. Proc. 4 th. Int. Coral Reef Symp. Manila 2: 339-344

Bouchon, C., Jaubert, J., Bouchon-Navaro, Y (1981). Evolution of a semiartificial reef built by transplanting coral heads. Tethys $10: 173-176$

Coles, S. L. (1984). Colonization of Hawaiian reef corals on new and denuded substrata in the vicinity of a Hawaiian power station. Coral Reefs 3: 123-130

Colgan, M. W (1981). Succession and recovery of a coral reef after predation by Acanthaster planci (L). Proc. 4th Coral Reef Symp., Manila 2: 333-338

Dinesen, Z. D. (1985). Aspects of the life history of a stolonbearing species of Efflatounaria (Octocorallia: Xeniidae). Proc. 5th Int. Coral Reef Congr., Tahiti 6:89-94

Fitzhardinge, R. (1985). Spatial und temporal variability in coral recruitment in Kaneohe Bay (Oahu, Hawai). Proc. 5th Int. Coral Reef Congr., Tahiti 4: 373-378

Foster, M. S. (1975). Regulation of algal community development in a Macrocystis pyrifera forest. Mar. Biol. 32: $331-342$

Grigg, R. W (1977). Population dynamics of two gorgonian corals. Ecology 58: 278-290

Harriott, V. J. (1985). Recruitment patterns of scleractinian corals at Lizard Island, Great Barrier Reef. Proc. 5th Int Coral Reef Congr., Tahiti 4:367-372
Hughes, T. P. (1985). Life histories and population dynamics of early successional corals. Proc. 5th Coral Reef Congr., Tahiti 4: 101-106

La Barre, S., Coll, J. C. (1982). Movement in soft corals: an interaction between Nephthea brassica (Coelenterata: Octocorallia) and Acropora hyacinthus (Coelenterata: Scleractinia). Mar Biol. 72: 119-124

Loya, Y. (1972). Community structure and species diversity of hermatypic corals at Eilat, Red Sea. Mar. Biol. 13: 100-123

Loya, Y (1976). The Red Sea coral Stylophora pistillata is an $r$ strategist. Nature, Lond. 259: 478-480

Neudecker, S. (1981). Effects of substratum orientation, depth, and time of coral recruitment at Guam. Proc. 4th Int. Coral Reef Symp., Manila 2: 376 (abstract)

Pearson, R. G. (1981). Recovery and recolonization of coral reefs. Mar. Ecol. Prog. Ser. 4: 105-122

Rogers, C. S., Carl Fitz, H., Gilnack, M., Beets, J., Hardin, J. (1984). Scleractinian coral recruitment patterns at Salt River, Submarine Canyon, St. Croix, U. S. Virgin Islands. Coral Reefs 3: 69-76

Sakai, K., Yamazato, K. (1984). Coral recruitment to artificially denuded natural substrates on an Okinawan reef flat. Glaxea 3: 57-69

Sammarco, P. W. (1985). A comparison of Caribbean reefs vs. the Great Barrier Reef: coral recruitment patterns and major grazers. Proc. 5th Int. Coral Reef Congr, Tahiti 4: 391-397

Schuhmacher, H. (1974). On the conditions accompanying the first settlement of corals on artificial reefs with special reference to the influence of grazing sea urchins (Eilat, Red Sea). Proc. 2nd Int. Coral Reef Symp., Brisbane 1: $257-260$

Sebens, K. P. (1983). The larval and juvenile ecology of the temperate octocoral Alcyonium siderium Verrill. I. Substratum selection by benthic larvae. J. exp. mar. Biol. Ecol. 71: 73-89

Wallace, C. C. (1985). Four years of juvenule coral recruitment to five reef front sites. Proc. 5th Int. Coral Reef Congr., Tahiti 4: 385-390

Wallace, C. C., Bull, G. D. (1981). Patterns of juvenile coral recruitment on a reef front during a spring-summer spawning period. Proc. 4 th Int. Coral Reef Symp., Manila 2: $345-350$ 